\title{
Hisse Senedi Getirilerinin Marka Değeri Duyurularına Tepkisi
}

\author{
Bahadır ERGÜN*
}

ÖZ

Bu çalışmada Türkiye marka değeri sıralamasında ilk 10'a girebilmiş firmalarının hisse senetlerinin bu duyuru öncesi ve sonrası ne şekilde fiyatlandığının araştırılması amaçlanmıştır. Bu bağlamda 2012 ve 2017 yılları arasında Brand Finance tarafından ilan edilen Türkiye'nin En Değerli Markaları Yıllık Raporu'na giren ilk 10 şirketin düzeltilmiş günlük hisse senedi fiyatları ve BIST100 endeksine ait günlük veriler kullanılmıştır. Analiz yöntemi olarak olay etüdü yöntemi seçilmiştir. Yapılan analiz sonrasında yatırımcıların marka değeri duyurularına verdikleri tepkinin daha çok ilk yıllarda istatistiksel olarak anlamlı ve pozitif olduğu gözlenmiştir. Diğer bir ifade ile ilk yıllardan itibaren benzer firmaların listeye girdiği bilgisi ışı̆̆ında, ilerleyen yıllarda marka değeri sıralamasında ilk 10'a girmesi muhtemel hisse senetlerine yatırım yaparak normalüstü getiri elde etme olasılığ1 azalmıştır. Bu durumun bilginin zaman geçtikçe fiyatlara yansıtılmış olmasından kaynaklandığı ileri sürülebilir.

Anahtar Kelimeler: Marka Değeri Duyuruları, Hisse Senedi Getirileri, Olay Etüdü

JEL Sinıflandırması: D53, G14, M31

\section{The Response of Stock Returns to the Brand Value Announcements}

\begin{abstract}
The aim of this study was to investigate how did the stocks of the firms, listed in the top 10 brand value list of Turkey, priced before and after the brand value announcements. In this context the adjusted stock prices of the firms entered the annual list of Turkey's first 10 most valuable brands announced by Brand Finance and the daily data of the BIST100 index were utilized for the period of 2012 and 2017. Event study methodology was employed for the analysis. After the analysis, statistically significant and positive reactions of the investors to the brand value announcements were observed substantially in the first years. In other words, in the light of the information that generally the same firms were listed from the beginning of the announcements, in the following years the possibility to have abnormal returns by investing in the stocks that possibly will enter to the list of most valuable brands decreased. It can be asserted that this might proceed from the reflection of information to the prices by the time of progress.
\end{abstract}

Keywords: Brand Value Announcements, Stock Returns, Event Study

JEL Classification: D53, G14, M31

Araştırma Makalesi - Geliş Tarihi / Received: 17.08.2018 Kabul Tarihi / Accepted: 09.12.2018

\footnotetext{
* Dr. Öğr. Üyesi, Adana Bilim ve Teknoloji Üniversitesi, İşletme Fakültesi, Uluslararası Ticaret ve Finans Bölümü, bergun@ adanabtu.edu.tr, ORCID: 0000-0002-0844-412X
} 


\section{GİRIŞ}

Firmalarla ilgili piyasaya gelen iyi ve kötü bilgilerin o firmanın hisse senedi fiyatlarına ne şekilde yansıdı $\breve{g} 1$ finans biliminde sıkça araştırılan konulardan biridir. Burada iyi bilgi ile kastedilen, özellikle şirketin karlılı̆̆ı, yeni pazarlara girilmesi, yeni yatırımlar yapması gibi pay sahiplerinin refahını arttırma potansiyeli olan bilgilerdir ki bunların hisse senedi fiyatını arttırıcı etkisi olacağını beklemek oldukça doğaldır.

Özellikle etkin piyasalar kavramı çerçevesinde düşünüldüğünde bilginin hisse senedi fiyatlarına yansıyıp yansımamasının yanında bu yansımanın zamanı da önem kazanmaktadır. Etkin Piyasalar Hipotezine (EPH) göre piyasaya gelen bilgiler yatırımcılar tarafından doğru bir şekilde fiyatlanır. Piyasalar fiyatlayabildikleri bilgilere göre farklı etkinlik seviyelerinde olabilir. Eğer yalnızca geçmiş bilgiler fiyatlara yansıtılmışsa, piyasa yarı-güçlü formda etkin bir piyasadır. Tarihi bilgilerin yanında halka açıklanan bilgiler fiyatlara yansıtılmış ise yarı-güçlü forma etkinlikten, tüm bu bilgilerin yanında halka açıklanmayan bilgiler de fiyatlara yansıtılmış ise güçlü-formda piyasa etkinliğinden bahsedilebilir (Fama, 1970, 383).

Firmaların sahip oldukları markalar önemli varlık kalemlerinden birisidir. Bu markaların değerli olması firmanın o markadan daha fazla gelir elde edebileceği anlamına gelebilmektedir. Clark (2002) markanın firmaların yönetebileceği en önemli maddi olmayan varlığı olduğunu ileri sürmüştür. Bu bağlamda bir firmanın markasının en değerli markalar listesinde yer alması yatırımcılar açısından iyi bir bilgidir ve bunun hisse senedi fiyatını arttırması beklenebilir.

Aaker'e (1996) göre "algılanan kalite" marka değerini oluşturan en önemli bileşenlerden biridir ve diğer bileşenlerle yüksek derecede ilişkilidir. Bunun yanında algılanan kalitenin etkilediği faktörlerden biri de hisse senedi getirileridir. Aaker'in çalışmaları bu ilişkiyi diğer araştırmacılar açısından daha görünür yapmasından dolayı önemlidir. Literatürde hisse senedi getirileri ve doğrudan marka değeri arasında pozitif yönlü bir ilişki olduğunu ileri süren çalışmalar da (Mizik ve Jocabson (2008); Madden ve diğerleri (2006); Barth ve diğerleri (1998) vb.) mevcuttur. Türkiye özelinde düşünüldüğünde Başgöze ve diğerlerinin (2016) çalışması literatürdeki önemli bir boşluğu doldurmasından dolayı önemli bir yere sahiptir.

Bu çalışmada Brand Finance tarafından hazırlanan Türkiye'nin en değerli markaları listesinde 2012-2017 yılları arasında ilk 10'a girebilmiş markaların hisse senedi fiyatlarının bu duyuruya olan tepkisinin olay etüdü yöntemiyle araştırılması amaçlanmıştır. Çalışma bazı benzerliklerinin yanında Başgöze ve diğerlerinin (2016) araştırmasından farklılaşmaktadır. Bunlardan bazıları aylık yerine günlük getiriler yardımıyla yatırımcıların kısa süreli tepkilerinin ölçülmesinin amaçlanması, olay penceresini olay gününden başlatmak yerine 10 gün öncesinden başlatarak marka değeri duyuruları öncesindeki muhtemel getiri hareketlerinin görülebilmesinin amaçlanması ve olay penceresini 20 gün ile sınırlandırarak yine kısa vadedeki tepkilerin gözlenmesinin amaçlanması olarak sıralanabilir.

Hisse senedi getirilerinin marka değeri duyurularına tepkisinin ortaya koyulmasının bu markalara sahip, marka değerini ve hisse senedi fiyatını arttırmayı hedefleyen firmalara, bu firmaların özellikle pazarlama ve finans departmanlarına ve bireysel-kurumsal yatırımcılara ve bu alanda yapılacak benzer akademik araştırmalara faydalı olabileceği düşünülmektedir. Bunların yanında sonuçların piyasaların etkinlik seviyeleri, bilginin fiyatlara yansıma zamanları hakkında bilgi verecek olması ise Borsa İstanbul ve Sermaye Piyasası Kurumu gibi düzenleyici ve denetleyici kurumlar açısından aydınlatıcı olacaktır. İlerleyen bölümlerde öncelikle marka ve marka değeri kavramına, ardından konu ile ilgili literatüre yer verilmiştir. Son olarak da araştırmada kullanılan veri ve yöntem belirtildikten sonra elde edilen bulgular ve sonuçlar açıklanmıştır. 


\section{MARKA VE MARKA DEĞERİ KAVRAMLARI}

Günümüz işletmecilik dünyasında marka kavramının önemi tartışılmaz bir konumdadır. İşletmeler daha değerli markalara sahip olabilmek için çeşitli stratejiler uygulamaktadırlar. Klasik tanıma göre marka bir ürünün tanınmasıyla ve belirli isim, logo, dizayn ve diğer görsel işaret ve semboller yardımıyla rakiplerinden ayırt edilmesi ile ilgilidir. Diğer taraftan marka yönetimi kitaplarının çok daha uç tanımlarıyla da karşılaşılabilmektedir ki bu durum marka kavramının farklı yönlerini ve zaman içindeki gelişimini kapsayabilme amacından kaynaklanmaktadır (Heding, Knudtzen ve Bjerre, 2009: 11). Firmalar açısından markalar müşteri davranışlarını etkileyebilen ve alınıp satılabilir nitelikte olan büyük değere sahip varlıklardır. Bu özelliklerinin yanında markalar sahiplerine gelecekteki gelirlerini sürdürülebilir bir seviyede tutabilme imkânını da tanıyabilmektedir (Kotler ve Keller, 2009:277-278).

Güçlü marka aynı zamanda yüksek marka değeri anlamına gelmektedir. Yüksek değere sahip markalar yüksek marka sadakati, isim bilinirliği, algılanan kalite ve marka çağrışımına da sahiptir. Firmalar açısından yüksek değerli bir marka değerli bir varlıktır (Kotler ve diğerleri, 1999: 572). Marka değerinin oluşumunda öne çıkan faktörler marka farkındalığı, markanın kabul edilebilirliği, marka tercihi ve markaya bağlllık olarak sıralanabilir. Marka değeri bilginin yorumu, satın alma kararlarında kolaylık ve tatmin konularında müşteriye katkı sağlarken; pazarlama programının etkinliği, marka sadakati, fiyat ve karın korunabilmesi, marka yayılımı, ticari başarı ve rekabet avantajı gibi konularda da firmaya katkı sağlamaktadır (Altunışık ve diğerleri, 2006: 155).

Finansal bakış açısına göre marka değeri, marka sayesinde kazanılan net ek nakit akışları ile ölçülür. Bu ek nakit akışları müşterilerin bir markayı, rakipleri daha düşük bir fiyatta dahi olsa, rakiplerinin markasından daha fazla tercih etmelerinin bir sonucudur. Markaların müşterilerin, dağıtımcıların ve kanaat önderlerinin zihinlerinde ve kalplerinde bir varlığa dönüşmüş olmalarından dolayı finansal değerleri vardır (Kapferer, 2008: 9-10).

Marka değerinin, işletmeler aşçısında ne kadar önemli bir varlık olduğu bilgisi 1şı̆̆ında yüksek marka değeri bilgisinin ilgili işletmenin hisse senetlerinin piyasa tarafından pozitif yönde fiyatlanacağını beklemek sürpriz olmayacaktır.

\section{LITERATÜR ARAŞTIRMASI}

Çalışmanın literatür taraması kısmında gerek doğrudan marka değerinin gerekse marka değerini oluşturan faktörlerden bazılarının hisse senedi getirilerine olan etkisini araştırmış bazı çalışmalara yer verilmiştir.

Aaker ve Jacobson (1994) firmaların gelecek başarısı konusunda hayati olan ve bilançoda görülemeyen faktörler arasında marka değerinin de olduğunu ileri sürmüşlerdir. Yazarlara göre marka itibarının temelinde kalite bulunmaktadır. Araştırmacılar firma değerinin bir göstergesi olan hisse senedi fiyatlarındaki hareketler ile algılanan kalitenin ilişkili olduğunu ve yöneticilerin markanın kalite imajı gibi bilgileri hisse senedi piyasasına aktarmalarının faydalı olacağını belirtmişlerdir.

Barth ve diğerleri (1998) 1991-1996 dönemi için 1204 marka değeri tahmininin hisse senedi fiyatlarına yansıma durumunu araştırmıştır. Yapılan analizler sonucunda bu tahminlerin hisse senedi fiyatları ve getirileri ile önemli ölçüde ilişkili olduğunu ifade etmişlerdir. Daha ayrıntılı olarak hisse senedi getirileri ile reklam harcamaları, marka faaliyet marjı, satış büyümesi ve markanın piyasa payı gibi değişkenler ilişkili bulunmuştur.

Aaker ve Jacobson (2001) ileri teknoloji piyasalarında marka değerinin temel bileşenlerinden sayılan marka tutumunun firmanın gelecek kazançlarını ve dolayısı ile de firma 
değerinin tahmini konusunda etkilerini araştırdıkları çalışmalarında marka tutumunda gerçekleşen değişimlerin hisse senedi getirileri ve finansal performanslanı ile ilişkili olduğunu ileri sürmüşlerdir.

Madden ve diğerleri (2006) pazarlamanın firma performansı üzerindeki etkilerini ele almıştır. Aynı zamanda hisse senedi getiri performansı üzerindeki etkilerini de incelemişlerdir. Finans biliminde yaygin olarak kullanılan Fama-French metodunu kullanarak yazarlar pazarlamanın hisse senedi getirilerine pozitif bir etki oluşturduğunu ifade etmiştir. Elde ettikleri sonuçlarda aynı zamanda güçlü markaların ilgili kriterlere göre daha büyük getiri sağlamakla kalmayıp, bunu daha az risk ile başardıklarını göstermişlerdir.

Fehle ve diğerleri (2008) 1994-2006 y1lları arasında Interbrand tarafindan yayınlanan listede yer alan değerli markalara sahip ABD firmalarının hisse senetlerinin piyasa üstü getiriler sağladığını ileri sürmüștür. Yazarlara göre marka değeri hisse senedi analizlerinde göz ardı edilmemesi gereken bir değişkendir.

Mizik ve Jocabson'a (2008) göre hisse senedi getirileri yalnızca muhasebe performans ölçütleriyle değil aynı zamanda algılanan marka uygunluğu ve enerjisi (perceived brand relevance and energy) ile de ilgilidir. Bu marka ölçütlerinin içerdiği bilgiler, finansal piyasaların firmanın gelecek nakit akışlarını tahmin ederken kullandığı bilgilerle ilişkilidir.

Beijer ve diğerleri (2008) marka değeri duyurularının firma değerine olan etkilerini araştırdıkları çalışmalarında olay etüdü yöntemini kullanmışlardır. Araştırmacılar önceki yıla göre gerçekleşen marka değeri değişimlerine hisse senedi fiyatlarının aynı yönde tepki verdiklerini belirtmişlerdir.

Bharadwaj, Tuli ve Bonfrer (2011) çalışmalarında yatırımcılar tarafından beklenmeyen marka kalitesi değişimlerinin hissedar refahı ile sistematik ve sistematik olmayan riske olan etkisini araştırdıkları çalışmalarında marka kalitesindeki bu değişikliklerin hissedar refahını hisse senedi getirileriyle pozitif, sistematik riskteki değişimler ile negatif ilişkili olduklarından arttırdıklarını ileri sürmüşlerdir. Bunun yanında diğer taraftan da beklenmeyen marka değeri değişimlerinin sistematik risk değişimleri ile pozitif ilişkili olması durumu da bu hissedar refahı artışında erozyona neden olabilmektedir.

Hsu ve diğerleri (2013) küresel markalara sahip firmalar için güçlü marka değerine sahip firmaların hisse senetlerinin piyasa endeksinden daha iyi getiriler sağlayıp sağlamadığını araştırdıkları çalışmalarında farklı elde tutma süreleri ile hazırlanan ve Interbrand Global 100 listesine giren hisse senetleri ile oluşturulan portföyün S\&P Endeksinden daha fazla getiriler elde ettiğini ileri sürmüşlerdir. Bunun yanında olay etüdü yöntemi ile de duyuru penceresinde bu hisse senetlerinin anormal getiri sağladıklarını da belirtmişlerdir.

Dutordoir ve diğerleri (2015) marka değeri duyurusu dönemlerinde pozitif getirilerin bekleneceğini ancak bunun nedenlerinin tam olarak ortaya koyulmadığını ileri sürmüşlerdir. Yazarlara göre bu pozitif fiyat hareketinin sebepleri nakit akışlarından zarar görebilirlik seviyesinin yüksek olması, değerli büyüme firsatları ve ileriki dönemlerde fiyat arttırmaya olanak sağlamasından kaynaklanabilir. Analiz sonucuna göre bu pozitif getirinin sebebi yatırımcıların firmanın şok durumlarındaki nakit akışlarından zarar görebilirlik seviyelerini azaltması durumunu fiyatlamalarından kaynaklandığını ileri sürmüşlerdir. Bunun yanında büyüme fırsatına ilişkin karmaşık sonuçlara ulaşırlarken yüksek fiyat koyabilme ile ilgili olarak bir kanıta ulaşamamışlardır.

Topuz ve Akşit (2016) 2001-2012 yılları arasındaki dönemde Interbrand tarafinda en iyi 100 marka listesine giren markalar ve bu firmaların hisse senedi getirileri arasındaki ilişkiyi araştırmıştır. Panel veri analizinin yapıldığ 1 araştırma sonucunda marka değeri duyurularının 
(cari değer ve gecikmeli değerlerinin) hisse senedi getirileri üzerinde anlamlı ve pozitif etkilerinin olduğu gözlenmiştir.

Başgöze ve diğerleri (2016) marka değeri duyurularının hisse senedi getirilerine etkilerini inceledikleri çalışmalarında 2010-2014 yılları arasında Türkiye'nin ilk 100 markası arasına girebilmiş firmaların aylık getirilerini veri seti olarak belirlemişlerdir. Olay etüdü yönteminin kullanıldığ 1 çalışmada olay penceresi, duyuru tarihi ile bundan 10 ay sonraki süreyi kapsamaktadır. Araştırma sonucunda firmaların duyurudan yedi ay sonra anormal pozitif getiriler kazandıklarını gözlemlemişlerdir.

\section{4. ÇALIŞMANIN KAPSAMI VE YÖNTEM}

$\mathrm{Bu}$ çalışmada marka değeri duyurularının listede ilk 10'a giren şirketlerin hisse senedi fiyatlarında kısa vadede herhangi bir etki yaratıp yaratmadığının ortaya koyulması amaçlanmıştır.

Marka değeri verileri marka değerleme ve stratejik danışmanlık faaliyetleri yürüten ve Türkiye'nin de içinde olduğu, dünyanın birçok ülkesine ait en değerli markaları yıllık olarak yayımlayan Londra merkezli Brand Finance şirketinden elde edilmiştir. Bunun yanında yapılan duyuruların hisse senedi fiyatına etkisini ortaya koyabilmek için 2012 ve 2017 yılları arasında Brand Finance tarafından yıllık olarak hazırlanmış Türkiye'nin En Değerli Markalarının Yıllık Raporu'na giren ilk 10 şirketin düzeltilmiş günlük hisse senedi fiyatları ve BIST100 endeksine ait günlük veriler kullanılmıştır.

Tablo 1: Türkiye'nin En Değerli Markalarının Yılık Raporu'nun Yayımlanma Tarihleri

\begin{tabular}{cc}
\hline Y11 & Olay Tarihleri \\
\hline 2017 & 15.06 .2017 \\
2016 & 15.06 .2016 \\
2015 & 15.06 .2015 \\
2014 & 10.06 .2014 \\
2013 & 03.07 .2013 \\
2012 & 12.09 .2012 \\
\hline
\end{tabular}

Kaynak: http://brandfinance.com/ (Erişim Tarihi: 12/08/2018)

Tablo 1'de 2012 ve 2017 yılları arasında Brand Finance tarafından hazırlanmış Türkiye'nin En Değerli Markalarının Yıılık Raporu'nun yayımlanma tarihleri görülebilir. Bu tarihler olay etüdü yönteminde olay tarihini (event date) vermeleri bakımından önem taşımaktadır. 
Tablo 2: Yıllara Göre En Değerli 10 Marka

\begin{tabular}{cllllll}
\hline Siralama & \multicolumn{1}{c}{2017} & \multicolumn{1}{c}{2016} & \multicolumn{1}{c}{2015} & \multicolumn{2}{c}{2014} & \multicolumn{2}{c}{2012} \\
\hline 1 & Türk Telekom & Turkish Airlines & Akbank & Türk Telekom & Türk Telekom & Türk Telekom \\
2 & Turkcell & Türk Telekom & Türk Telekom & Akbank & Akbank & Turkish Airlines \\
3 & Turkish Airlines & Arcelik & Isbank & Turkish Airlines & Isbank & Akbank \\
4 & Akbank & Akbank & Turkish Airlines & Isbank & Turkish Airlines & Isbank \\
5 & Garanti & Garanti & Garanti & Arcelik & Garanti & Turkcell \\
6 & Ziraat Bankasi & Turkcell & Arcelik & Anadolu Efes & Turkcell & Anadolu Efes \\
7 & Arcelik & Isbank & Turkcell & Garanti & Arcelik & Garanti \\
8 & Isbank & Anadolu Efes & Yapi Kredi & Turkcell & Bim & Arcelik \\
9 & Yapi Kredi & Yapi Kredi & Bim & Bim & Anadolu Efes & Yapi Kredi \\
10 & Halkbank & Halkbank & Anadolu Efes & Yapi Kredi & Yapi Kredi & Petrol Ofisi \\
\hline
\end{tabular}

Kaynak: http://brandfinance.com/ (Erişim Tarihi: 12/08/2018)

Tablo 2'de 2012 ve 2017 yılları arasındaki dönemde Brand Finance tarafindan yayımlanan Türkiye'nin En Değerli Markalarının Yıllık Raporlarından derlenen ilk 10'a girebilmiş markalar görülebilmektedir. Burada aynı markanın farklı yıllarda üste üste birçok kez listeye girebildiği unutulmamalıdır. Bu bakış açısıyla, yıllardan bağımsız olarak listeye girebilmiş marka sayısı 15 olarak karşımıza çıkmaktadır. Söz konusu markalar Türk Telekom, Turkcell, Turkish Airlines, Akbank, Garanti, Ziraat Bankasi, Arcelik, Isbank, Yapi Kredi, Halkbank, Anadolu Efes, Türk Telekom, Turkcell, Bim ve Petrol Ofisi olarak sıralanabilir. Diğer taraftan Zirrat Bankası'nın hisse senetlerinin Borsa İstanbul'da işlem görmemesinden dolayı analiz dışında bırakılmıştır.

Brand Finance "hak bedeli" yaklaşımı ile markaları değerlemektedir. Hak bedeli yaklaşımındaki temel mantık firmanın ilgili markaya sahip olmaması durumunda eğer bu markayı başka bir firmadan lisanslasaydı bunun için ödemesi gereken lisans-hak bedeli tutarının belirlenmesi üzerinedir. Bu yöntemde gelecekteki satışların tahmin edilmesi, bu tahminlere uygun bir hak bedeli oranının uyarlanması, bu bedelin uygun iskonto oranı yardımıyla bugünkü değerlerinin bulunması ve son olarak da net bugünkü değere ulaşılması amaçlanır (Brand Finance 100, 2017; Brand Finance 100, 2016 (Erişim Tarihi: 12/08/2018)).

Marka değeri duyurularının hisse senedi getirilerindeki etkisini ortaya koyabilmek amacıyla olay etüdü (event study) yönteminden yararlanılmıştır. Olay etüdü yöntemi akademik muhasebe ve finans alanında şirket birleşme-satın alma, karlılık, yeni borç ya da özkaynak ihracı duyurularının yanında ticaret açığı gibi makroekonomik duyuruların etkilerini ölçmek için kullanılmaktadır (Campbell vd. 1997:149). Bu yöntem yardımıyla finansal piyasa verileri kullanılarak belirli bir olayın firma değerine etkisi ortaya koyulabilmektedir (Mac Kinlay, 1997:13). Bunun yanında piyasa ile ilgili olaylarda da kullanılmaktadır (Agrawal ve Kamakura, 1995:57). 


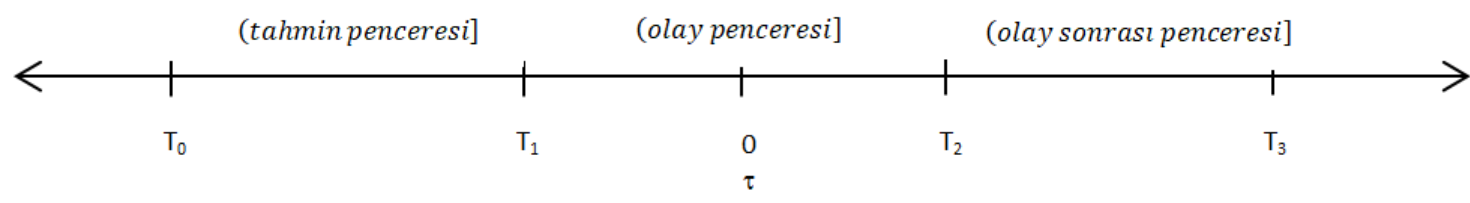

Şekil 1. Olay Etüdü Zaman Çizgisi

Kaynak: (Campbell vd. 1997:157)

Şekil 1'de tipik bir olay etüdü metodolojisinin periyotları görülmektedir. Burada $\tau=0$ olay gününü, $\tau=\mathrm{T}_{1}+1$ 'den $\tau=\mathrm{T}_{2}$ 'ye kadar olan süre olay penceresini, $\tau=\mathrm{T}_{0}+1$ 'den $\tau=\mathrm{T}_{1}$ 'e kadar süre tahmin süresini göstermektedir (Mac Kinlay, 1997:19).

Campbell vd. (1997) olay etüdü yönteminin uygulanmasının tek bir şeklinin olmadığını, buna rağmen genel olarak yedi aşamadan oluştuğunu belirtmişlerdir. Bu aşamalar olayın tanımlanması, seçim kriterlerinin belirlenmesi, normal ve anormal getirilerin hesaplanması, normal performans (piyasa modeli) modeli seçildiyse parametrelerin tahmin süreci, test süreci, ampirik bulguların elde edilmesi ve son olarak da bulguların yorumlanarak sonuca ulaşılması olarak siralanabilir.

Literatürde farklı uzunlukta olay pencerelerine sahip çalışmalara rağmen McWilliams ve Siegel'e (1997) bu sürenin uzun tutulması çeşitli yönlerden sakıncalar doğurmaktadır ve mümkün olduğunca kısa olmalıdır.

Olay etüdü yöntemleri genel olarak birbirine benzemekle birlikte temel farklılaşma anormal getirilerin hesaplanması aşamasında kendini göstermektedir. Bu çalışmada anormal getirilerin hesaplanması yaklaşımlarından piyasa modeli yaklaşımı kullanılacaktır.

Marka değeri listesinde ilk 10'a giren firmaların hisse senedi getirilerinde herhangi bir etki yaşanıp yaşanmadığının test edildiği bu araştırmada olay penceresi \pm 10 gün, tahmin penceresi ise bu olay penceresinden önceki 100 gün olarak belirlenmiştir. Diğer bir deyişle -11 . $\mathrm{Ve}-110$. günlerin arasındaki dönem bu çalışmanın tahmin penceresini oluştururken -10 . ve +10 . Günler arasındaki periyot ise olay penceresini oluşturmuştur. Her yıl için olayı (marka değeri duyurusu) kapsayan toplam 121 günlük veriden faydalanılmıştır ve aşağıdaki formüller yardımıyla analiz yapııııştır.

$$
R_{i t}=\ln \left(\frac{P_{t}}{P_{t-1}}\right)
$$

$R_{i t}:$ hisse senedi getirisi,

$P_{t}$ : hisse senedinin $\mathrm{t}$ dönemindeki kapanış fiyatı,

$P_{t-1}: \mathrm{t}-1$ dönemindeki kapanış fiyatı.

Piyasa modelinin tahmin hataları $\left(\epsilon_{i t}\right)$ bize anormal getirileri verecektir (Cowan ve Sergeant, 1996:1734).

$R_{i t}=\alpha_{i}+\beta_{i} R_{m t}+\epsilon_{i t}$

$R_{i t}:$ i hisse senedinin t zamanındaki getirisi,

$R_{m t}:$ t zamanındaki piyasa getirisi

$\alpha_{i}$ : modeldeki sabit katsayı (kesme)

$\beta_{i}$ : hisse senedi betas1 (eğim)

Anormal getirinin $\left(A R_{i t}\right)$ hesaplanması için; 


$$
A R_{i t}=R_{i t}-\left(\hat{\alpha}+\hat{\beta} R_{m t}\right)
$$

Olay penceresindeki günlere ait ortalama anormal getirinin $\left(A A R_{i t}\right)$ hesaplanması için;

$$
A A R_{t}=\frac{1}{N} \sum_{t=1}^{N} A R_{i t}
$$

Olay penceresindeki -10 . Günden başlayarak kümülatif ortalama anormal getirinin $C A A R_{i}$ hesaplanması için;

$$
C A A R_{t}=\sum_{t=-10}^{10} A A R_{t}
$$

formülleri kullanılmıştır.

Son olarak ortalama anormal getirilerin $\mathrm{t}$ istatistiğinin hesaplanması için aşağıdaki formüllerden yararlanılmıştır (Brown ve Warner, 1985,7).

$$
\begin{aligned}
& t=\frac{A A R}{S\left(A A R_{t}\right)} \\
& S\left(A A R_{t}\right)=\sqrt{\frac{1}{99} \sum_{t=-110}^{t=-11}\left(A A R_{t}-\overline{A R R}\right)^{2}} \\
& \overline{A R R}=\frac{1}{100} \sum_{t=-110}^{t=-11} A A R_{t}
\end{aligned}
$$

$\mathrm{Bu}$ bağlamda olay penceresi sonunda pozitif $\operatorname{CAAR}_{i}\left(T_{1} T_{2}\right)$ değerleri, en değerli marka listesinde yer almanın, belirtilen süre içerisinde, hisse senedi getirileri üzerinde olumlu etkisi olduğu anlamına gelecektir.

\section{BULGULAR}

Çalışmanın bu bölümünde olay etüdü yöntemi yardımıyla, marka değeri duyurularının hisse senedi getirilerinde nasıl bir etkiye sahip olduğuna dair bulgulara yer verilmiştir. 
Tablo 3: 2012 yılında İlk 10'a giren firmaların hisse senetlerinin Anormal Getirileri (AR) ve Ortalama Anormal Getirileri (AAR)

\begin{tabular}{|c|c|c|c|c|c|c|c|c|c|c|c|c|}
\hline $\mathrm{T}$ & TTKOM & THYAO & AKBNK & ISCTR & TCELL & AEFES & GARAN & ARCLK & YKBNK & PTOFS & AAR & t-ist AAR \\
\hline 10 & $-0.32 \%$ & $2.66 \%$ & $0.50 \%$ & $1.16 \%$ & $-0.12 \%$ & $-1.57 \%$ & $0.95 \%$ & $-1.74 \%$ & $0.87 \%$ & $-1.23 \%$ & $0.12 \%$ & 0.3193 \\
\hline 9 & $-3.20 \%$ & $0.37 \%$ & $0.61 \%$ & $1.42 \%$ & $-0.31 \%$ & $0.71 \%$ & $0.66 \%$ & $-0.76 \%$ & $1.15 \%$ & $1.44 \%$ & $0.21 \%$ & 0.5742 \\
\hline 8 & $2.25 \%$ & $0.75 \%$ & $-0.07 \%$ & $0.91 \%$ & $0.26 \%$ & $-2.61 \%$ & $-0.50 \%$ & $0.36 \%$ & $1.01 \%$ & $-0.74 \%$ & $0.16 \%$ & 0.4461 \\
\hline 7 & $-2.14 \%$ & $-0.80 \%$ & $0.93 \%$ & $2.74 \%$ & $1.62 \%$ & $-1.02 \%$ & $0.35 \%$ & $-1.01 \%$ & $0.33 \%$ & $-0.32 \%$ & $0.07 \%$ & 0.1896 \\
\hline 6 & $0.18 \%$ & $-0.60 \%$ & $0.56 \%$ & $-0.66 \%$ & $-0.40 \%$ & $-1.43 \%$ & $-0.04 \%$ & $-1.12 \%$ & $0.21 \%$ & $0.03 \%$ & $-0.33 \%$ & -0.9022 \\
\hline 5 & $1.46 \%$ & $0.97 \%$ & $-0.18 \%$ & $-1.70 \%$ & $-1.32 \%$ & $1.42 \%$ & $-0.36 \%$ & $2.15 \%$ & $-1.76 \%$ & $-0.75 \%$ & $-0.01 \%$ & -0.0183 \\
\hline 4 & $-0.21 \%$ & $0.72 \%$ & $-1.00 \%$ & $-1.28 \%$ & $0.93 \%$ & $0.69 \%$ & $-0.86 \%$ & $-4.19 \%$ & $0.35 \%$ & $0.67 \%$ & $-0.42 \%$ & -1.1532 \\
\hline 3 & $-0.41 \%$ & $1.94 \%$ & $-0.34 \%$ & $0.03 \%$ & $0.93 \%$ & $-0.71 \%$ & $-0.86 \%$ & $-2.98 \%$ & $-0.76 \%$ & $-0.99 \%$ & $-0.41 \%$ & -1.1421 \\
\hline 2 & $-2.93 \%$ & $-2.34 \%$ & $-0.49 \%$ & $-0.20 \%$ & $1.21 \%$ & $0.11 \%$ & $0.04 \%$ & $3.73 \%$ & $0.29 \%$ & $0.47 \%$ & $-0.01 \%$ & -0.0307 \\
\hline 1 & $-1.31 \%$ & $0.02 \%$ & $0.33 \%$ & $0.27 \%$ & $1.41 \%$ & $-0.53 \%$ & $-1.07 \%$ & $3.49 \%$ & $0.09 \%$ & $2.54 \%$ & $0.52 \%$ & 1.4445 \\
\hline 0 & $0.74 \%$ & $0.92 \%$ & $0.19 \%$ & $-0.31 \%$ & $-0.62 \%$ & $1.41 \%$ & $-0.16 \%$ & $-2.29 \%$ & $0.93 \%$ & $2.06 \%$ & $0.29 \%$ & 0.7923 \\
\hline-1 & $0.86 \%$ & $-1.01 \%$ & $-0.19 \%$ & $-0.47 \%$ & $1.35 \%$ & $1.12 \%$ & $0.29 \%$ & $-1.68 \%$ & $0.23 \%$ & $-2.74 \%$ & $-0.23 \%$ & -0.6206 \\
\hline-2 & $0.63 \%$ & $-1.04 \%$ & $-0.01 \%$ & $-0.53 \%$ & $0.67 \%$ & $1.38 \%$ & $-0.88 \%$ & $-1.84 \%$ & $-0.67 \%$ & $2.13 \%$ & $-0.02 \%$ & -0.0438 \\
\hline-3 & $0.32 \%$ & $1.75 \%$ & $-0.64 \%$ & $0.46 \%$ & $-4.04 \%$ & $3.16 \%$ & $0.32 \%$ & $0.53 \%$ & $0.63 \%$ & $5.14 \%$ & $0.76 \%$ & 2.1004 \\
\hline-4 & $-0.14 \%$ & $-0.22 \%$ & $0.32 \%$ & $-0.47 \%$ & $-0.70 \%$ & $0.87 \%$ & $-1.33 \%$ & $0.11 \%$ & $-0.84 \%$ & $0.14 \%$ & $-0.23 \%$ & -0.6279 \\
\hline-5 & $-0.20 \%$ & $3.07 \%$ & $0.21 \%$ & $-0.09 \%$ & $2.88 \%$ & $-0.08 \%$ & $0.20 \%$ & $1.13 \%$ & $0.13 \%$ & $-1.75 \%$ & $0.55 \%$ & 1.5165 \\
\hline-6 & $1.24 \%$ & $-0.89 \%$ & $0.08 \%$ & $-0.58 \%$ & $0.29 \%$ & $-0.01 \%$ & $0.36 \%$ & $0.53 \%$ & $-0.52 \%$ & $0.68 \%$ & $0.12 \%$ & 0.3204 \\
\hline-7 & $0.79 \%$ & $2.18 \%$ & $-0.20 \%$ & $0.90 \%$ & $-1.76 \%$ & $-2.51 \%$ & $0.06 \%$ & $0.30 \%$ & $1.72 \%$ & $0.50 \%$ & $0.20 \%$ & 0.5446 \\
\hline-8 & $-0.30 \%$ & $-0.10 \%$ & $-1.13 \%$ & $-0.50 \%$ & $2.79 \%$ & $0.71 \%$ & $-0.65 \%$ & $2.13 \%$ & $-1.32 \%$ & $-1.54 \%$ & $0.01 \%$ & 0.0234 \\
\hline-9 & $0.31 \%$ & $-1.96 \%$ & $0.03 \%$ & $-0.91 \%$ & $1.37 \%$ & $-3.19 \%$ & $0.23 \%$ & $-0.46 \%$ & $0.41 \%$ & $2.49 \%$ & $-0.17 \%$ & -0.4607 \\
\hline-10 & $0.08 \%$ & $-0.55 \%$ & $-0.04 \%$ & $0.17 \%$ & $1.18 \%$ & $1.40 \%$ & $0.38 \%$ & $-2.45 \%$ & $0.72 \%$ & $-1.23 \%$ & $-0.03 \%$ & -0.0939 \\
\hline
\end{tabular}

Tablo 3'te Brand Finance tarafindan hazırlanmış 2012 yılı için Türkiye'nin En Değerli Markalarının Yıllık Raporunda ilk 10'a girmeyi başarmış şirket hisse senetlerine ait AR ve AAR değerleri görülmektedir. Burada en ilgi çekici bulgu olaydan (marka değeri duyurusu) 3 gün önce gerçekleşen istatistiksel olarak anlamlı \%0.76'llk AAR değeridir. Bu bulgu marka değeri duyurularının içeriğinin piyasa tarafından doğru tahmin edilebileceği anlamına gelebileceği gibi ilgili kuruluşun marka değeri bilgilerini gerek kamuoyuyla gerekse listedeki firmalarla paylaşma politikasından kaynaklanabileceği unutulmamalıdır. $\mathrm{Bu}$ sebeple, olay etüdü yönteminin piyasanın özellikle yarı-güçlü forma etkinliğinin ölçülmesinde kullanılan bir yöntem olmasına karşılık, piyasanın bilgisel etkinlik seviyesi hakkında yorum yapmak yanıltıcı olabilecektir. Ancak şu kesindir ki piyasa gelen ya da gelecek pozitif bilgiyi olay tarihi öncesinde fiyatlamıştır. Bunun yanında gerek olay gününde gerekse diğer günlerde anlamlı sonuçlara ulaşılamamıştır. 
Tablo 4: 2013 yılında İlk 10'a giren firmaların hisse senetlerinin Anormal Getirileri (AR) ve Ortalama Anormal Getirileri (AAR)

\begin{tabular}{|c|c|c|c|c|c|c|c|c|c|c|c|c|}
\hline $\mathrm{T}$ & ТTКОМ & AKBNK & ISCTR & THYAO & GARAN & TCELL & ARCLK & BIMAS & AEFES & YKBNK & AAR & t-ist AAR \\
\hline 10 & $-0.65 \%$ & $2.53 \%$ & $0.81 \%$ & $-3.04 \%$ & $1.71 \%$ & $-0.49 \%$ & $-0.74 \%$ & $1.10 \%$ & $-1.42 \%$ & $0.26 \%$ & $0.01 \%$ & 0.0184 \\
\hline 9 & $-1.93 \%$ & $1.44 \%$ & $0.19 \%$ & $0.57 \%$ & $-0.34 \%$ & $-1.74 \%$ & $-0.56 \%$ & $-1.80 \%$ & $0.98 \%$ & $0.98 \%$ & $-0.22 \%$ & -0.6992 \\
\hline 8 & $-2.58 \%$ & $1.32 \%$ & $1.30 \%$ & $-3.95 \%$ & $0.74 \%$ & $0.57 \%$ & $1.85 \%$ & $-1.12 \%$ & $-1.64 \%$ & $0.55 \%$ & $-0.30 \%$ & -0.9426 \\
\hline 7 & $-1.07 \%$ & $2.31 \%$ & $-0.30 \%$ & $-2.54 \%$ & $0.04 \%$ & $0.70 \%$ & $-0.93 \%$ & $1.80 \%$ & $-3.83 \%$ & $-0.02 \%$ & $-0.38 \%$ & -1.2280 \\
\hline 6 & $0.14 \%$ & $-0.80 \%$ & $-1.54 \%$ & $-1.87 \%$ & $-1.30 \%$ & $-1.38 \%$ & $0.90 \%$ & $2.98 \%$ & $0.77 \%$ & $-1.07 \%$ & $-0.32 \%$ & -1.0132 \\
\hline 5 & $0.14 \%$ & $-2.17 \%$ & $-0.78 \%$ & $2.19 \%$ & $-0.55 \%$ & $-1.04 \%$ & $1.04 \%$ & $1.36 \%$ & $4.98 \%$ & $1.21 \%$ & $0.64 \%$ & 2.0409 \\
\hline 4 & $-1.20 \%$ & $0.15 \%$ & $-1.60 \%$ & $4.45 \%$ & $-2.70 \%$ & $2.03 \%$ & $-0.13 \%$ & $0.24 \%$ & $-0.91 \%$ & $-0.78 \%$ & $-0.05 \%$ & -0.1453 \\
\hline 3 & $-0.53 \%$ & $-1.23 \%$ & $0.53 \%$ & $3.05 \%$ & $-1.09 \%$ & $2.00 \%$ & $-1.83 \%$ & $0.35 \%$ & $-0.20 \%$ & $0.23 \%$ & $0.13 \%$ & 0.4049 \\
\hline 2 & $0.47 \%$ & $-1.63 \%$ & $-1.74 \%$ & $2.45 \%$ & $-1.23 \%$ & $1.70 \%$ & $1.59 \%$ & $0.13 \%$ & $0.91 \%$ & $-0.31 \%$ & $0.24 \%$ & 0.7529 \\
\hline 1 & $-0.41 \%$ & $0.05 \%$ & $0.61 \%$ & $-0.11 \%$ & $-0.22 \%$ & $0.65 \%$ & $-1.10 \%$ & $1.20 \%$ & $-3.69 \%$ & $-0.22 \%$ & $-0.32 \%$ & -1.0303 \\
\hline 0 & $0.26 \%$ & $-0.37 \%$ & $-0.63 \%$ & $1.42 \%$ & $0.07 \%$ & $-2.06 \%$ & $5.17 \%$ & $0.47 \%$ & $1.76 \%$ & $0.24 \%$ & $0.63 \%$ & 2.0252 \\
\hline-1 & $-0.38 \%$ & $0.53 \%$ & $0.18 \%$ & $-0.86 \%$ & $0.28 \%$ & $-0.62 \%$ & $1.41 \%$ & $-1.17 \%$ & $-4.08 \%$ & $0.53 \%$ & $-0.42 \%$ & -1.3404 \\
\hline-2 & $-1.79 \%$ & $-0.09 \%$ & $-0.63 \%$ & $0.43 \%$ & $-1.70 \%$ & $1.94 \%$ & $-1.86 \%$ & $-0.85 \%$ & $-1.15 \%$ & $0.83 \%$ & $-0.49 \%$ & -1.5524 \\
\hline-3 & $3.83 \%$ & $1.05 \%$ & $-1.13 \%$ & $-3.14 \%$ & $-1.14 \%$ & $1.02 \%$ & $1.19 \%$ & $3.70 \%$ & $3.85 \%$ & $-2.50 \%$ & $0.67 \%$ & 2.1527 \\
\hline-4 & $1.14 \%$ & $-0.54 \%$ & $1.64 \%$ & $3.36 \%$ & $-0.68 \%$ & $-0.87 \%$ & $-0.90 \%$ & $-0.18 \%$ & $2.19 \%$ & $0.04 \%$ & $0.52 \%$ & 1.6611 \\
\hline-5 & $-1.21 \%$ & $1.01 \%$ & $0.95 \%$ & $-1.17 \%$ & $0.76 \%$ & $2.28 \%$ & $-0.21 \%$ & $0.15 \%$ & $3.99 \%$ & $-0.06 \%$ & $0.65 \%$ & 2.0692 \\
\hline-6 & $0.57 \%$ & $-2.26 \%$ & $-0.52 \%$ & $7.19 \%$ & $-0.53 \%$ & $-0.86 \%$ & $1.23 \%$ & $-1.30 \%$ & $0.64 \%$ & $0.91 \%$ & $0.51 \%$ & 1.6192 \\
\hline-7 & $-0.54 \%$ & $-0.77 \%$ & $-1.46 \%$ & $-0.12 \%$ & $1.18 \%$ & $-0.91 \%$ & $4.77 \%$ & $2.83 \%$ & $4.01 \%$ & $-1.45 \%$ & $0.75 \%$ & 2.4055 \\
\hline-8 & $3.71 \%$ & $-2.96 \%$ & $-1.16 \%$ & $-3.03 \%$ & $0.65 \%$ & $0.31 \%$ & $-1.41 \%$ & $-1.20 \%$ & $-0.23 \%$ & $-0.49 \%$ & $-0.58 \%$ & -1.8551 \\
\hline-9 & $-2.52 \%$ & $1.69 \%$ & $0.28 \%$ & $4.47 \%$ & $1.54 \%$ & $-0.22 \%$ & $-1.03 \%$ & $-2.16 \%$ & $1.66 \%$ & $-1.53 \%$ & $0.22 \%$ & 0.6964 \\
\hline-10 & $-1.24 \%$ & $0.36 \%$ & $-0.29 \%$ & $-0.83 \%$ & $-0.18 \%$ & $1.98 \%$ & $0.17 \%$ & $2.72 \%$ & $0.98 \%$ & $-1.63 \%$ & $0.20 \%$ & 0.6476 \\
\hline
\end{tabular}

2013 yılında İlk 10'a giren firmaların hisse senetlerinin Anormal Getirileri (AR), Ortalama Anormal Getiri (AAR) ve t istatistiği değerleri Tablo 4'te görülmektedir. En değerli markalar listesinin yayımlanmasından 7 gün $(\% 0.75), 5$ gün $(\% 0.65)$ ve 3 gün $(\% 0.67)$ önce, olay gününde $(\% 0.63)$ ve olaydan 5 gün $(\% 0.64)$ sonra anlamlı ve pozitif AAR değeri bulunmuştur. Bu bilgiler 1şığında aynı 2012 yılında olduğu gibi piyasanın gelen ya da gelecek olan bilgiyi pozitif fiyatladığ 1,2012 yılından farklı olarak olay günüde ve bundan 5 gün sonra da bu eğilimin devam ettiği ileri sürülebilmektedir.

Tablo 5: 2014 yılında İlk 10'a giren firmaların hisse senetlerinin Anormal Getirileri (AR) ve Ortalama Anormal Getirileri (AAR)

\begin{tabular}{|c|c|c|c|c|c|c|c|c|c|c|c|c|}
\hline $\mathrm{T}$ & TTKOM & AKBNK & THYAO & ISCTR & ARCLK & AEFES & GARAN & TCELL & BIMAS & YKBNK & AAR & t-ist AAR \\
\hline 10 & $1.08 \%$ & $-1.16 \%$ & $-0.19 \%$ & $-0.21 \%$ & $-0.33 \%$ & $0.74 \%$ & $-0.90 \%$ & $1.01 \%$ & $0.35 \%$ & $0.05 \%$ & $0.04 \%$ & 0.1448 \\
\hline 9 & $-0.36 \%$ & $1.16 \%$ & $-1.07 \%$ & $1.63 \%$ & $1.31 \%$ & $1.30 \%$ & $1.79 \%$ & $-1.05 \%$ & $-0.46 \%$ & $0.15 \%$ & $0.44 \%$ & 1.4713 \\
\hline 8 & $-0.88 \%$ & $0.41 \%$ & $-0.11 \%$ & $0.09 \%$ & $-1.14 \%$ & $-2.59 \%$ & $-0.44 \%$ & $0.09 \%$ & $-0.05 \%$ & $-0.09 \%$ & $-0.47 \%$ & -1.5724 \\
\hline 7 & $0.24 \%$ & $0.11 \%$ & $-0.97 \%$ & $-0.33 \%$ & $1.67 \%$ & $-1.48 \%$ & $-0.30 \%$ & $-0.32 \%$ & $1.65 \%$ & $1.64 \%$ & $0.19 \%$ & 0.6364 \\
\hline 6 & $0.17 \%$ & $-0.43 \%$ & $0.38 \%$ & $-0.53 \%$ & $-0.83 \%$ & $-2.78 \%$ & $-1.13 \%$ & $-0.82 \%$ & $0.16 \%$ & $-0.64 \%$ & $-0.65 \%$ & -2.1643 \\
\hline 5 & $-0.30 \%$ & $-0.33 \%$ & $0.18 \%$ & $-0.99 \%$ & $0.01 \%$ & $-0.13 \%$ & $-0.13 \%$ & $-1.03 \%$ & $-2.18 \%$ & $-1.78 \%$ & $-0.67 \%$ & -2.2371 \\
\hline 4 & $-1.42 \%$ & $-1.19 \%$ & $0.89 \%$ & $-1.70 \%$ & $2.44 \%$ & $0.65 \%$ & $-0.35 \%$ & $-0.50 \%$ & $2.47 \%$ & $-0.87 \%$ & $0.04 \%$ & 0.1352 \\
\hline 3 & $0.59 \%$ & $0.10 \%$ & $-2.12 \%$ & $0.20 \%$ & $-0.97 \%$ & $-1.02 \%$ & $1.32 \%$ & $0.59 \%$ & $0.40 \%$ & $0.19 \%$ & $-0.07 \%$ & -0.2394 \\
\hline 2 & $1.51 \%$ & $-0.65 \%$ & $-1.08 \%$ & $-1.64 \%$ & $-0.50 \%$ & $1.64 \%$ & $-0.86 \%$ & $2.04 \%$ & $1.42 \%$ & $-0.75 \%$ & $0.11 \%$ & 0.3806 \\
\hline 1 & $0.32 \%$ & $1.69 \%$ & $-1.17 \%$ & $1.67 \%$ & $-0.40 \%$ & $2.02 \%$ & $1.27 \%$ & $1.50 \%$ & $0.35 \%$ & $1.02 \%$ & $0.83 \%$ & 2.7719 \\
\hline 0 & $1.10 \%$ & $0.15 \%$ & $-0.90 \%$ & $-0.29 \%$ & $1.32 \%$ & $4.00 \%$ & $-0.12 \%$ & $1.27 \%$ & $-0.42 \%$ & $-0.07 \%$ & $0.60 \%$ & 2.0198 \\
\hline-1 & $-1.39 \%$ & $0.56 \%$ & $-0.81 \%$ & $0.40 \%$ & $-0.74 \%$ & $-2.07 \%$ & $-0.57 \%$ & $-1.78 \%$ & $-0.52 \%$ & $-0.85 \%$ & $-0.78 \%$ & -2.6020 \\
\hline-2 & $-0.19 \%$ & $-0.11 \%$ & $0.44 \%$ & $-0.29 \%$ & $-1.40 \%$ & $-2.57 \%$ & $-0.56 \%$ & $3.45 \%$ & $-1.05 \%$ & $-1.23 \%$ & $-0.35 \%$ & -1.1748 \\
\hline-3 & $0.26 \%$ & $-0.22 \%$ & $-0.38 \%$ & $0.47 \%$ & $-3.11 \%$ & $-1.19 \%$ & $0.94 \%$ & $-2.59 \%$ & $0.21 \%$ & $0.36 \%$ & $-0.52 \%$ & -1.7569 \\
\hline-4 & $1.50 \%$ & $-0.51 \%$ & $-0.74 \%$ & $-0.41 \%$ & $-0.57 \%$ & $0.60 \%$ & $-0.61 \%$ & $-0.46 \%$ & $2.85 \%$ & $-1.27 \%$ & $0.04 \%$ & 0.1290 \\
\hline-5 & $0.74 \%$ & $-1.61 \%$ & $-1.02 \%$ & $0.02 \%$ & $-0.89 \%$ & $0.01 \%$ & $-0.10 \%$ & $-0.12 \%$ & $1.90 \%$ & $-0.56 \%$ & $-0.16 \%$ & -0.5462 \\
\hline-6 & $0.40 \%$ & $-1.33 \%$ & $1.61 \%$ & $-0.92 \%$ & $3.04 \%$ & $-0.22 \%$ & $-0.44 \%$ & $-1.07 \%$ & $0.85 \%$ & $-0.90 \%$ & $0.10 \%$ & 0.3439 \\
\hline-7 & $0.26 \%$ & $-0.99 \%$ & $0.17 \%$ & $1.48 \%$ & $1.20 \%$ & $-3.62 \%$ & $-0.23 \%$ & $5.88 \%$ & $-1.05 \%$ & $0.76 \%$ & $0.39 \%$ & 1.2997 \\
\hline-8 & $-0.41 \%$ & $-0.11 \%$ & $-0.40 \%$ & $1.03 \%$ & $-1.08 \%$ & $0.18 \%$ & $-0.75 \%$ & $-0.54 \%$ & $-0.80 \%$ & $0.95 \%$ & $-0.19 \%$ & -0.6484 \\
\hline-9 & $0.29 \%$ & $-0.65 \%$ & $-0.96 \%$ & $-0.25 \%$ & $0.67 \%$ & $1.12 \%$ & $-1.38 \%$ & $-0.74 \%$ & $1.76 \%$ & $0.67 \%$ & $0.05 \%$ & 0.1737 \\
\hline-10 & $0.22 \%$ & $0.11 \%$ & $0.17 \%$ & $-0.99 \%$ & $0.92 \%$ & $0.08 \%$ & $-0.40 \%$ & $-0.82 \%$ & $-2.73 \%$ & $0.17 \%$ & $-0.33 \%$ & -1.0964 \\
\hline
\end{tabular}


Tablo 5 incelendiğinde ilk göze çarpan noktalardan biri olay penceresi boyunca gerçekleşmiş pozitif ve negatif ve de istatistiksel olarak anlamlı AAR değerleri ile bu bulguların daha çok olay sonrasında gerçekleşmiş olmasıdır. Bu bağlamda tek istisna olay gününden bir gün önce gerçekleşen - $\% 0.78$ 'lik negatif getiridir. Olay günü gerçekleşen $\% 0.60$ 'lık AAR duyuruya verilen pozitif tepkiyi, olay sonrasından bir gün sonraki \%0.83'lük AAR bu tepkinin devam ettiğini gösterirken olay sonrasındaki beşinci ve altıncı günlerde gerçekleşen \%-0.67 ve $\%-0.65$ 'lik getiriler de yatırımcı algısının tersine döndüğü anlamına gelebilmektedir.

Tablo 6: 2015 yılında Illk 10'a giren firmaların hisse senetlerinin Anormal Getirileri (AR) ve Ortalama Anormal Getirileri (AAR)

\begin{tabular}{|c|c|c|c|c|c|c|c|c|c|c|c|c|}
\hline $\mathrm{T}$ & AKBNK & TTKOM & ISCTR & THYAO & GARAN & ARCLK & TCELL & YKBNK & BIMAS & AEFES & AAR & t-ist AAR \\
\hline 10 & $1.14 \%$ & $-0.57 \%$ & $1.67 \%$ & $-0.37 \%$ & $0.51 \%$ & $0.11 \%$ & $-1.40 \%$ & $1.14 \%$ & $-0.37 \%$ & $-0.86 \%$ & $0.10 \%$ & 0.3504 \\
\hline 9 & $-0.60 \%$ & $0.28 \%$ & $0.95 \%$ & $-1.04 \%$ & $0.35 \%$ & $0.10 \%$ & $-0.56 \%$ & $-0.07 \%$ & $-0.50 \%$ & $1.16 \%$ & $0.01 \%$ & 0.0296 \\
\hline 8 & $-0.53 \%$ & $-2.01 \%$ & $0.52 \%$ & $1.74 \%$ & $0.28 \%$ & $0.36 \%$ & $0.70 \%$ & $0.20 \%$ & $0.73 \%$ & $-1.56 \%$ & $0.04 \%$ & 0.1451 \\
\hline 7 & $-0.31 \%$ & $-0.39 \%$ & $-0.46 \%$ & $0.46 \%$ & $-0.47 \%$ & $-0.23 \%$ & $-0.37 \%$ & $-0.07 \%$ & $-0.14 \%$ & $1.98 \%$ & $0.00 \%$ & 0.0010 \\
\hline 6 & $-1.44 \%$ & $-0.32 \%$ & $-0.38 \%$ & $-1.01 \%$ & $-1.25 \%$ & $-0.07 \%$ & $1.51 \%$ & $-0.33 \%$ & $-0.57 \%$ & $-1.01 \%$ & $-0.48 \%$ & -1.6812 \\
\hline 5 & $-0.03 \%$ & $1.09 \%$ & $-0.47 \%$ & $-0.64 \%$ & $0.52 \%$ & $-1.55 \%$ & $1.33 \%$ & $0.33 \%$ & $1.92 \%$ & $-1.49 \%$ & $0.10 \%$ & 0.3486 \\
\hline 4 & $-0.19 \%$ & $2.36 \%$ & $-0.55 \%$ & $0.39 \%$ & $-0.37 \%$ & $0.58 \%$ & $0.05 \%$ & $-0.47 \%$ & $-1.64 \%$ & $0.19 \%$ & $0.04 \%$ & 0.1253 \\
\hline 3 & $-0.87 \%$ & $-1.09 \%$ & $-1.65 \%$ & $-0.42 \%$ & $-1.49 \%$ & $-0.03 \%$ & $0.34 \%$ & $-0.31 \%$ & $0.27 \%$ & $0.45 \%$ & $-0.48 \%$ & -1.6626 \\
\hline 2 & $-0.34 \%$ & $-1.38 \%$ & $1.76 \%$ & $0.84 \%$ & $0.21 \%$ & $-0.49 \%$ & $0.46 \%$ & $0.02 \%$ & $-2.38 \%$ & $1.47 \%$ & $0.02 \%$ & 0.0615 \\
\hline 1 & $-0.65 \%$ & $0.03 \%$ & $-0.60 \%$ & $0.02 \%$ & $-0.82 \%$ & $-1.12 \%$ & $-0.09 \%$ & $0.18 \%$ & $1.18 \%$ & $0.68 \%$ & $-0.12 \%$ & -0.4110 \\
\hline 0 & $0.71 \%$ & $-0.14 \%$ & $-0.13 \%$ & $1.18 \%$ & $0.03 \%$ & $1.75 \%$ & $-0.80 \%$ & $-0.44 \%$ & $2.15 \%$ & $-2.29 \%$ & $0.20 \%$ & 0.7009 \\
\hline-1 & $-0.28 \%$ & $-0.79 \%$ & $0.43 \%$ & $-0.42 \%$ & $1.37 \%$ & $-0.81 \%$ & $1.12 \%$ & $-0.16 \%$ & $-0.83 \%$ & $-1.45 \%$ & $-0.18 \%$ & -0.6302 \\
\hline-2 & $0.11 \%$ & $1.59 \%$ & $-0.90 \%$ & $0.21 \%$ & $0.43 \%$ & $-0.28 \%$ & $0.02 \%$ & $0.38 \%$ & $1.98 \%$ & $-0.54 \%$ & $0.30 \%$ & 1.0410 \\
\hline-3 & $0.62 \%$ & $-2.18 \%$ & $0.73 \%$ & $0.35 \%$ & $-0.67 \%$ & $-0.39 \%$ & $-0.39 \%$ & $-0.95 \%$ & $-0.22 \%$ & $0.86 \%$ & $-0.22 \%$ & -0.7801 \\
\hline-4 & $0.97 \%$ & $-3.07 \%$ & $0.52 \%$ & $-0.63 \%$ & $1.39 \%$ & $-1.76 \%$ & $-0.23 \%$ & $2.45 \%$ & $-0.80 \%$ & $1.59 \%$ & $0.04 \%$ & 0.1483 \\
\hline-5 & $2.45 \%$ & $0.45 \%$ & $-0.17 \%$ & $-0.97 \%$ & $0.43 \%$ & $2.96 \%$ & $-0.84 \%$ & $-1.73 \%$ & $-0.02 \%$ & $2.98 \%$ & $0.55 \%$ & 1.9221 \\
\hline-6 & $0.14 \%$ & $2.19 \%$ & $3.17 \%$ & $0.03 \%$ & $0.75 \%$ & $-1.28 \%$ & $0.47 \%$ & $0.72 \%$ & $-0.54 \%$ & $-0.29 \%$ & $0.54 \%$ & 1.8625 \\
\hline-7 & $-0.37 \%$ & $2.36 \%$ & $-1.20 \%$ & $1.58 \%$ & $0.68 \%$ & $-0.29 \%$ & $1.14 \%$ & $-0.46 \%$ & $-1.12 \%$ & $-1.83 \%$ & $0.05 \%$ & 0.1694 \\
\hline-8 & $-1.46 \%$ & $0.58 \%$ & $-0.13 \%$ & $-0.62 \%$ & $-1.48 \%$ & $-1.04 \%$ & $2.29 \%$ & $0.21 \%$ & $1.72 \%$ & $-0.56 \%$ & $-0.05 \%$ & -0.1680 \\
\hline-9 & $0.62 \%$ & $-0.90 \%$ & $0.23 \%$ & $-0.11 \%$ & $1.03 \%$ & $1.55 \%$ & $0.55 \%$ & $-0.72 \%$ & $-0.83 \%$ & $-3.43 \%$ & $-0.20 \%$ & -0.6993 \\
\hline-10 & $0.90 \%$ & $1.65 \%$ & $0.50 \%$ & $0.65 \%$ & $1.22 \%$ & $0.11 \%$ & $2.02 \%$ & $0.66 \%$ & $-1.99 \%$ & $-1.46 \%$ & $0.43 \%$ & 1.4778 \\
\hline
\end{tabular}

2015 yılında İlk 10'a giren firmaların hisse senetlerinin Anormal Getirileri (AR) ve Ortalama Anormal Getirilerinin (AAR) gösterildiği Tablo 6'da yatırımcıların ilgili olaya olay penceresi boyunca anlamlı bir tepki göstermedikleri ileri sürülebilmektedir. Tüm AAR değerleri için $\mathrm{t}$ istatistiği değerleri sıfirdan farklı olma olasılıklarının oldukça düşük olduğunu göstermektedir. $\mathrm{Bu}$ durum önceki yıllarda da benzer firmaların markalarının listeye girmiş olmasından kaynaklanabilir. Diğer bir ifade ile bu firmaların listeye girmesi hisse senedi yatırımcıları için artık beklenmeyen bir durum olmaktan çıkmış olabilir. Örneğin bu liste 2014 yılının listesi ile karşılaştırıldığında aynı firmalar farklı bir sıralama ile karşımıza çıkmıştır. 
Tablo 7: 2016 yılında İlk 10’a giren firmaların hisse senetlerinin Anormal Getirileri (AR) ve Ortalama Anormal Getirileri (AAR)

\begin{tabular}{|c|c|c|c|c|c|c|c|c|c|c|c|c|}
\hline T & THYAO & TTKOM & ARCLK & AKBNK & GARAN & TCELL & ISCTR & AEFES & YKBNK & HALKB & AAR & t-ist AAR \\
\hline 10 & $-2.17 \%$ & $1.26 \%$ & $-1.60 \%$ & $-0.54 \%$ & $-1.21 \%$ & $2.33 \%$ & $-0.92 \%$ & $2.92 \%$ & $-0.58 \%$ & $-0.75 \%$ & $-0.13 \%$ & -0.3013 \\
\hline 9 & $-0.83 \%$ & $0.15 \%$ & $0.76 \%$ & $-1.96 \%$ & $-0.22 \%$ & $-0.09 \%$ & $-1.10 \%$ & $0.52 \%$ & $-1.95 \%$ & $-1.30 \%$ & $-0.60 \%$ & -1.4500 \\
\hline 8 & $4.34 \%$ & $-0.60 \%$ & $-1.43 \%$ & $-0.43 \%$ & $0.34 \%$ & $-1.24 \%$ & $0.19 \%$ & $0.76 \%$ & $-0.08 \%$ & $-0.77 \%$ & $0.11 \%$ & 0.2590 \\
\hline 7 & $1.04 \%$ & $-0.54 \%$ & $-2.01 \%$ & $2.00 \%$ & $-0.63 \%$ & $1.33 \%$ & $0.16 \%$ & $0.16 \%$ & $-1.28 \%$ & $-0.65 \%$ & $-0.04 \%$ & -0.0978 \\
\hline 6 & $-0.38 \%$ & $0.50 \%$ & $-0.09 \%$ & $1.11 \%$ & $0.33 \%$ & $0.04 \%$ & $0.52 \%$ & $0.45 \%$ & $-1.16 \%$ & $0.35 \%$ & $0.17 \%$ & 0.4012 \\
\hline 5 & $-1.27 \%$ & $0.31 \%$ & $-0.87 \%$ & $-0.21 \%$ & $1.07 \%$ & $-0.10 \%$ & $0.71 \%$ & $-2.78 \%$ & $-1.19 \%$ & $-0.16 \%$ & $-0.45 \%$ & -1.0818 \\
\hline 4 & $2.80 \%$ & $-1.63 \%$ & $-2.91 \%$ & $0.29 \%$ & $-0.38 \%$ & $-0.40 \%$ & $0.74 \%$ & $-1.42 \%$ & $-1.33 \%$ & $4.24 \%$ & $0.00 \%$ & 0.0015 \\
\hline 3 & $-1.74 \%$ & $0.82 \%$ & $-0.13 \%$ & $-0.39 \%$ & $0.35 \%$ & $1.20 \%$ & $-0.68 \%$ & $2.18 \%$ & $-0.31 \%$ & $-0.96 \%$ & $0.03 \%$ & 0.0797 \\
\hline 2 & $-1.16 \%$ & $0.48 \%$ & $1.43 \%$ & $1.65 \%$ & $-0.23 \%$ & $-0.10 \%$ & $0.03 \%$ & $-4.00 \%$ & $1.20 \%$ & $-0.01 \%$ & $-0.07 \%$ & -0.1685 \\
\hline 1 & $1.03 \%$ & $-0.76 \%$ & $1.48 \%$ & $0.67 \%$ & $1.12 \%$ & $-0.77 \%$ & $-0.40 \%$ & $0.96 \%$ & $0.45 \%$ & $0.48 \%$ & $0.43 \%$ & 1.0252 \\
\hline 0 & $-0.92 \%$ & $1.10 \%$ & $-1.45 \%$ & $-0.14 \%$ & $0.08 \%$ & $-2.01 \%$ & $1.38 \%$ & $-0.54 \%$ & $0.15 \%$ & $-0.53 \%$ & $-0.29 \%$ & -0.6907 \\
\hline-1 & $2.69 \%$ & $-1.22 \%$ & $-2.77 \%$ & $0.79 \%$ & $0.95 \%$ & $-1.40 \%$ & $1.07 \%$ & $-0.26 \%$ & $0.51 \%$ & $1.44 \%$ & $0.18 \%$ & 0.4354 \\
\hline-2 & $-1.50 \%$ & $-0.61 \%$ & $0.18 \%$ & $0.30 \%$ & $-0.10 \%$ & $0.39 \%$ & $-0.05 \%$ & $0.12 \%$ & $0.38 \%$ & $-1.72 \%$ & $-0.26 \%$ & -0.6286 \\
\hline-3 & $-1.31 \%$ & $-0.47 \%$ & $-1.53 \%$ & $0.48 \%$ & $0.22 \%$ & $0.73 \%$ & $0.23 \%$ & $-0.20 \%$ & $0.81 \%$ & $0.07 \%$ & $-0.10 \%$ & -0.2344 \\
\hline-4 & $1.25 \%$ & $0.47 \%$ & $0.64 \%$ & $0.24 \%$ & $0.14 \%$ & $-0.34 \%$ & $0.23 \%$ & $0.96 \%$ & $0.25 \%$ & $1.38 \%$ & $0.52 \%$ & 1.2558 \\
\hline-5 & $-0.82 \%$ & $-0.45 \%$ & $1.20 \%$ & $0.79 \%$ & 0.9 & $1 \%$ & $-0.05 \%$ & $-0.92 \%$ & $0.37 \%$ & $0.02 \%$ & $0.19 \%$ & 0.4690 \\
\hline-6 & $-1.12 \%$ & $0.80 \%$ & $1.96 \%$ & $-1.57 \%$ & $-0.38 \%$ & $-1.66 \%$ & $0.75 \%$ & $1.19 \%$ & $-0.97 \%$ & $0.80 \%$ & $-0.02 \%$ & -0.0469 \\
\hline-7 & $-0.36 \%$ & $-0.06 \%$ & $-2.12 \%$ & $0.03 \%$ & $0.39 \%$ & $-0.24 \%$ & $0.07 \%$ & $0.77 \%$ & $1.42 \%$ & $-0.36 \%$ & $-0.04 \%$ & -0.1079 \\
\hline-8 & $-0.66 \%$ & $1.43 \%$ & $2.17 \%$ & $-0.65 \%$ & $0.53 \%$ & $-0.08 \%$ & $-0.75 \%$ & $1.89 \%$ & $-1.07 \%$ & $-0.71 \%$ & $0.21 \%$ & 0.5052 \\
\hline-9 & $1.13 \%$ & $-0.22 \%$ & $-1.41 \%$ & $-0.13 \%$ & $0.24 \%$ & $-0.26 \%$ & $-0.32 \%$ & $1.34 \%$ & $-1.26 \%$ & $0.96 \%$ & $0.01 \%$ & 0.0175 \\
\hline-10 & $-0.17 \%$ & $-2.40 \%$ & $1.50 \%$ & $0.39 \%$ & $-0.95 \%$ & $1.22 \%$ & $-0.30 \%$ & $-2.47 \%$ & $-0.49 \%$ & $1.86 \%$ & $-0.18 \%$ & -0.4337 \\
\hline
\end{tabular}

2016 y1lındaki verileri gösteren Tablo 7'ye göre de bulgular 2015 yılındakilerle benzerlik göstermektedir. Anlamlı AAR değerlerine ulaşılamamıştır. 2015 yılında BIMAS ilk 10'da yer alırken 2016 yılında listeden çıkarak yerine HALKB girmiştir. Bunun yanında sıralamadaki değişiklikler dışında bu iki yılın listesi yine aynıdır. Bu bağlamda AAR değerlerinin istatistiksel olarak anlamsız bulunması, yatırımcıların beklenmeyen bir durum ile karşılaşmamaları ile açıklanabilir.

Tablo 8: 2017 yılında İlk 10'a giren firmaların hisse senetlerinin Anormal Getirileri (AR) ve Ortalama Anormal Getirileri (AAR)

\begin{tabular}{|c|c|c|c|c|c|c|c|c|c|c|c|}
\hline $\mathrm{T}$ & TTKOM & TCELL & THYAO & AKBNK & GARAN & ARCLK & ISCTR & YKBNK & HALKB & AAR & $\mathrm{t}$-ist AAR \\
\hline 10 & $-0.29 \%$ & $0.67 \%$ & $-0.06 \%$ & $0.29 \%$ & $0.76 \%$ & $-1.09 \%$ & $-0.41 \%$ & $0.41 \%$ & $-0.18 \%$ & $0.01 \%$ & 0.0294 \\
\hline 9 & $-1.17 \%$ & $0.04 \%$ & $2.63 \%$ & $-1.18 \%$ & $-1.12 \%$ & $0.62 \%$ & $0.16 \%$ & $-0.07 \%$ & $-0.20 \%$ & $-0.03 \%$ & -0.0923 \\
\hline 8 & $0.43 \%$ & $0.14 \%$ & $-1.82 \%$ & $-0.14 \%$ & $0.09 \%$ & $-1.88 \%$ & $1.12 \%$ & $0.07 \%$ & $0.74 \%$ & $-0.14 \%$ & -0.3792 \\
\hline 7 & $-0.72 \%$ & $-1.13 \%$ & $1.46 \%$ & $-0.98 \%$ & $0.85 \%$ & $1.06 \%$ & $0.08 \%$ & $-0.29 \%$ & $-0.33 \%$ & $0.00 \%$ & 0.0002 \\
\hline 6 & $0.44 \%$ & $0.75 \%$ & $2.69 \%$ & $-0.42 \%$ & $-0.21 \%$ & $-0.19 \%$ & $0.73 \%$ & $-0.14 \%$ & $0.45 \%$ & $0.45 \%$ & 1.2582 \\
\hline 5 & $-0.26 \%$ & $0.28 \%$ & $1.04 \%$ & $-0.14 \%$ & $-0.44 \%$ & $0.71 \%$ & $-0.59 \%$ & $-0.28 \%$ & $-0.44 \%$ & $-0.01 \%$ & -0.0372 \\
\hline 4 & $0.49 \%$ & $-0.22 \%$ & $0.30 \%$ & $0.03 \%$ & $-0.12 \%$ & $-0.20 \%$ & $-0.61 \%$ & $0.13 \%$ & $-0.56 \%$ & $-0.09 \%$ & -0.2372 \\
\hline 3 & $-0.38 \%$ & $-0.10 \%$ & $-0.54 \%$ & $-0.19 \%$ & $0.16 \%$ & $-1.36 \%$ & $0.20 \%$ & $-0.93 \%$ & $-0.89 \%$ & $-0.45 \%$ & -1.2366 \\
\hline 2 & $0.15 \%$ & $0.15 \%$ & $0.89 \%$ & $0.98 \%$ & $0.31 \%$ & $-0.46 \%$ & $-0.28 \%$ & $0.35 \%$ & $0.34 \%$ & $0.27 \%$ & 0.7449 \\
\hline 1 & $-0.15 \%$ & $0.05 \%$ & $-0.60 \%$ & $0.86 \%$ & $0.16 \%$ & $1.46 \%$ & $0.62 \%$ & $1.16 \%$ & $1.14 \%$ & $0.52 \%$ & 1.4441 \\
\hline 0 & $-1.09 \%$ & $-1.07 \%$ & $0.00 \%$ & $0.48 \%$ & $0.69 \%$ & $1.06 \%$ & $0.16 \%$ & $0.12 \%$ & $1.22 \%$ & $0.17 \%$ & 0.4807 \\
\hline-1 & $-0.26 \%$ & $-1.76 \%$ & $1.25 \%$ & $0.21 \%$ & $0.39 \%$ & $-1.24 \%$ & $1.16 \%$ & $0.02 \%$ & $-0.76 \%$ & $-0.11 \%$ & -0.3033 \\
\hline-2 & $-0.02 \%$ & $0.94 \%$ & $-0.85 \%$ & $0.43 \%$ & $-0.65 \%$ & $0.02 \%$ & $-0.94 \%$ & $-0.36 \%$ & $0.03 \%$ & $-0.15 \%$ & -0.4288 \\
\hline-3 & $-0.18 \%$ & $0.20 \%$ & $-0.86 \%$ & $1.20 \%$ & $0.45 \%$ & $-2.06 \%$ & $0.51 \%$ & $0.45 \%$ & $-0.74 \%$ & $-0.11 \%$ & -0.3157 \\
\hline-4 & $0.55 \%$ & $0.22 \%$ & $-0.52 \%$ & $-0.34 \%$ & $-0.56 \%$ & $-0.09 \%$ & $-0.44 \%$ & $-0.04 \%$ & $1.92 \%$ & $0.08 \%$ & 0.2157 \\
\hline-5 & $-1.07 \%$ & $0.38 \%$ & $-1.77 \%$ & $-0.98 \%$ & $-1.11 \%$ & $0.67 \%$ & $-0.84 \%$ & $-0.70 \%$ & $-0.04 \%$ & $-0.61 \%$ & -1.6817 \\
\hline-6 & $-1.79 \%$ & $-1.08 \%$ & $-0.09 \%$ & $0.50 \%$ & $0.84 \%$ & $-0.25 \%$ & $1.02 \%$ & $1.43 \%$ & $1.49 \%$ & $0.23 \%$ & 0.6368 \\
\hline-7 & $0.62 \%$ & $-0.31 \%$ & $0.68 \%$ & $0.10 \%$ & $0.58 \%$ & $-0.75 \%$ & $-0.51 \%$ & $-0.13 \%$ & $-0.46 \%$ & $-0.02 \%$ & -0.0540 \\
\hline-8 & $-0.23 \%$ & $-1.17 \%$ & $2.84 \%$ & $0.64 \%$ & $0.05 \%$ & $0.41 \%$ & $0.67 \%$ & $0.00 \%$ & $0.85 \%$ & $0.45 \%$ & 1.2498 \\
\hline-9 & $-1.15 \%$ & $-0.24 \%$ & $-0.37 \%$ & $-0.87 \%$ & $-0.76 \%$ & $4.48 \%$ & $-0.51 \%$ & $-0.65 \%$ & $-1.77 \%$ & $-0.20 \%$ & -0.5629 \\
\hline-10 & $-0.78 \%$ & $-0.10 \%$ & $-1.10 \%$ & $0.39 \%$ & $-0.71 \%$ & $1.60 \%$ & $-0.34 \%$ & $-0.78 \%$ & $0.02 \%$ & $-0.20 \%$ & -0.5580 \\
\hline
\end{tabular}


Tablo 8'deki bilgiler 1şı̆̆ında 2017 yılında İlk 10'a giren firmaların hisse senetlerinin Anormal Getirileri (AR) ve Ortalama Anormal Getirileri (AAR) incelendiğinde de son üç yılda piyasanın marka değeri duyurularına istatistiksel olarak anlamlı tepkiler vermediği görülmektedir. Aynı önceki yıllarda olduğu gibi bu durum marka değeri duyurusunun içeriğinin beklenmeyen bir durum olmaktan çıkması ile açıklanabilir.

Tablo 9: Yıllara göre gerçekleşen Kümülatif Ortalama Anormal Getiri (CAAR) değerleri

\begin{tabular}{|c|c|c|c|c|c|c|c|}
\hline $\mathrm{T}$ & CAAR 2012 & CAAR 2013 & CAAR 2014 & CAAR 2015 & CAAR 2016 & CAAR 2017 & Ortalama \\
\hline 10 & $1.15 \%$ & $2.09 \%$ & $-1.35 \%$ & $0.68 \%$ & $-0.33 \%$ & $0.06 \%$ & $0.38 \%$ \\
\hline 9 & $1.04 \%$ & $2.09 \%$ & $-1.40 \%$ & $0.58 \%$ & $-0.20 \%$ & $0.05 \%$ & $0.36 \%$ \\
\hline 8 & $0.83 \%$ & $2.31 \%$ & $-1.83 \%$ & $0.57 \%$ & $0.40 \%$ & $0.09 \%$ & $0.39 \%$ \\
\hline 7 & $0.67 \%$ & $2.60 \%$ & $-1.37 \%$ & $0.53 \%$ & $0.29 \%$ & $0.22 \%$ & $0.49 \%$ \\
\hline 6 & $0.60 \%$ & $2.99 \%$ & $-1.56 \%$ & $0.53 \%$ & $0.33 \%$ & $0.22 \%$ & $0.52 \%$ \\
\hline 5 & $0.93 \%$ & $3.30 \%$ & $-0.91 \%$ & $1.01 \%$ & $0.16 \%$ & $-0.23 \%$ & $0.71 \%$ \\
\hline 4 & $0.93 \%$ & $2.66 \%$ & $-0.24 \%$ & $0.91 \%$ & $0.61 \%$ & $-0.22 \%$ & $0.78 \%$ \\
\hline 3 & $1.35 \%$ & $2.71 \%$ & $-0.28 \%$ & $0.87 \%$ & $0.61 \%$ & $-0.13 \%$ & $0.86 \%$ \\
\hline 2 & $1.77 \%$ & $2.58 \%$ & $-0.21 \%$ & $1.35 \%$ & $0.58 \%$ & $0.31 \%$ & $1.06 \%$ \\
\hline 1 & $1.78 \%$ & $2.35 \%$ & $-0.32 \%$ & $1.34 \%$ & $0.65 \%$ & $0.04 \%$ & $0.97 \%$ \\
\hline 0 & $1.25 \%$ & $2.67 \%$ & $-1.15 \%$ & $1.45 \%$ & $0.22 \%$ & $-0.48 \%$ & $0.66 \%$ \\
\hline-1 & $0.97 \%$ & $2.04 \%$ & $-1.75 \%$ & $1.25 \%$ & $0.51 \%$ & $-0.65 \%$ & $0.39 \%$ \\
\hline-2 & $1.19 \%$ & $2.46 \%$ & $-0.98 \%$ & $1.43 \%$ & $0.33 \%$ & $-0.54 \%$ & $0.65 \%$ \\
\hline-3 & $1.21 \%$ & $2.94 \%$ & $-0.63 \%$ & $1.13 \%$ & $0.59 \%$ & $-0.39 \%$ & $0.81 \%$ \\
\hline-4 & $0.44 \%$ & $2.27 \%$ & $-0.10 \%$ & $1.36 \%$ & $0.69 \%$ & $-0.27 \%$ & $0.73 \%$ \\
\hline-5 & $0.67 \%$ & $1.75 \%$ & $-0.14 \%$ & $1.32 \%$ & $0.17 \%$ & $-0.35 \%$ & $0.57 \%$ \\
\hline-6 & $0.12 \%$ & $1.10 \%$ & $0.02 \%$ & $0.76 \%$ & $-0.03 \%$ & $0.26 \%$ & $0.37 \%$ \\
\hline-7 & $0.00 \%$ & $0.59 \%$ & $-0.08 \%$ & $0.22 \%$ & $-0.01 \%$ & $0.03 \%$ & $0.13 \%$ \\
\hline-8 & $-0.19 \%$ & $-0.16 \%$ & $-0.47 \%$ & $0.18 \%$ & $0.04 \%$ & $0.05 \%$ & $-0.09 \%$ \\
\hline-9 & $-0.20 \%$ & $0.42 \%$ & $-0.28 \%$ & $0.22 \%$ & $-0.17 \%$ & $-0.40 \%$ & $-0.07 \%$ \\
\hline-10 & $-0.03 \%$ & $0.20 \%$ & $-0.33 \%$ & $0.43 \%$ & $-0.18 \%$ & $-0.20 \%$ & $-0.02 \%$ \\
\hline
\end{tabular}

Tablo 9'da her bir yıl için gerçekleşmiş olan CAAR değerleri ve son olarak da tüm örneklemin olay penceresindeki günlere göre ortalaması yer almaktadır. Buna göre 2012 yılı incelendiğinde en yüksek CAAR değerine marka değeri duyurusundan sonraki gün $\left(t_{+1}\right)$ ulaşırken en düşük değeri ise olaydan dokuz gün önce (t-9) gerçekleşmiştir. 2013 y1lında en yüksek CAAR değeri $t_{+5}$ 'te en düşük değeri $t_{-8}$ 'de gözlenmiştir. 2015 yılında en yüksek değerin olay günü olan $t_{0}$ 'da, en düşük değerin ise $t_{-}$' de olduğu görülmektedir. 2017 için ise en yüksek değer $t_{+2}$ 'de en düşük değer ise $t_{-1}$ 'dedir.

Yukarıda belirtilen yıllarda en düşük değerler olay penceresi içinde en yüksek değerlerden önce gerçekleşirken, bu sayılan yıllardan farklı olarak 2014 ve 2016 yıllarında CAAR değerleri olay penceresinin ortalarında en yüksek değerini alırken sonlarında da en düşük değerlerini almışlardır. CAAR değerlerinin 2014'te dönem boyunca negatif, 2016'da ise dönem başında ve sonunda negatif seyrettiği görülmektedir. 2014 en yüksek değeri t-6'da, en düşük değeri $t_{+8}$ 'de, 2016 en yükssek değeri $t_{-4}$ 'te, en düşük değeri $t_{+10}$ ' da gerçekleşmiştir. 


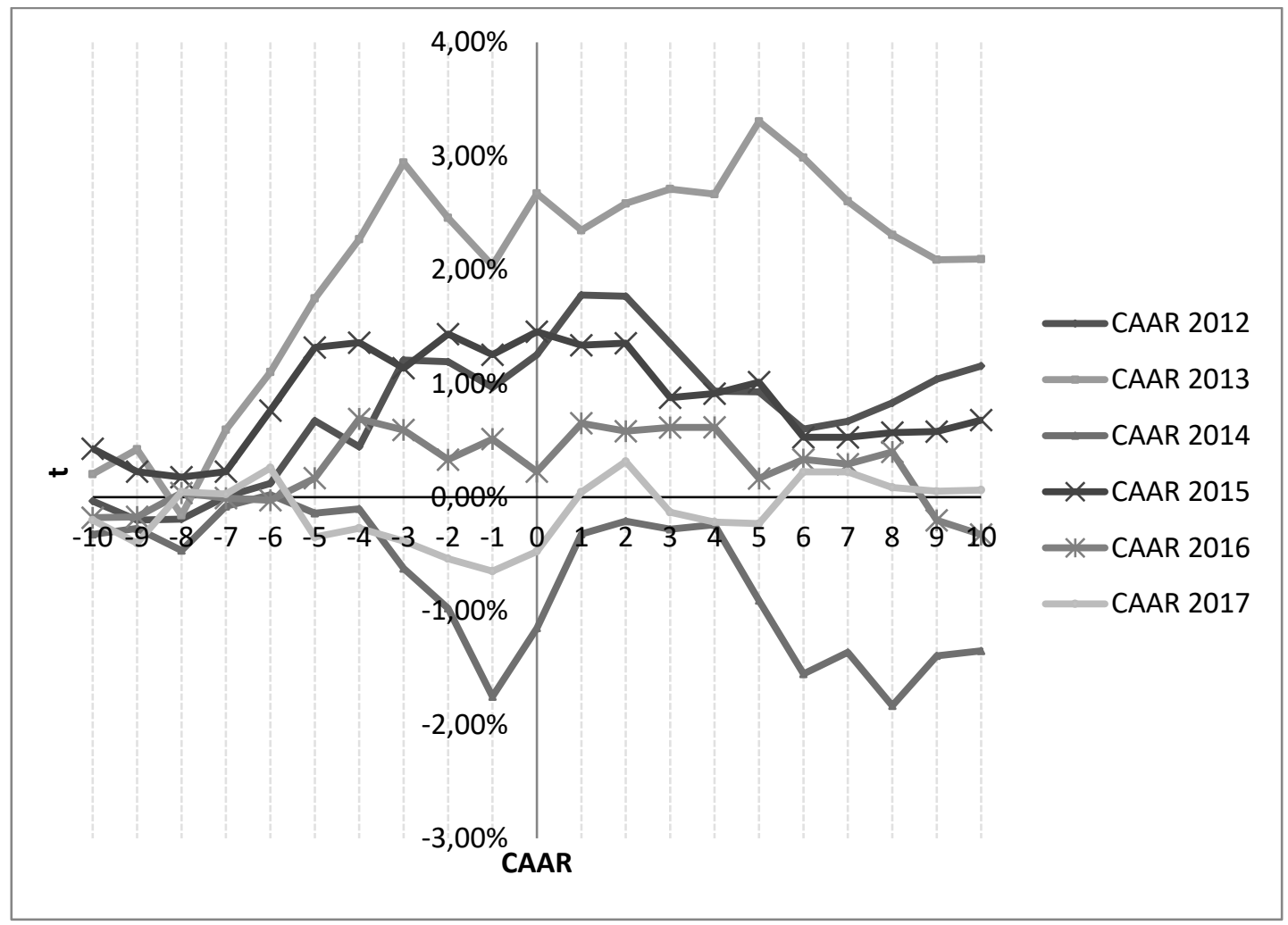

Şekil 2. Kümülatif Ortalama Anormal Getiri (CAAR) Değerleri

CAAR değerlerinin olay penceresi içindeki seyirleri Şekil 2'de daha rahat görülebilir. Buna göre elde edilebilen en yüksek kümülatif ortalama anormal getirilerin önceki bulgulara paralel olarak araştırma periyodunun ilk yıllarında olduğu gözlenmektedir.

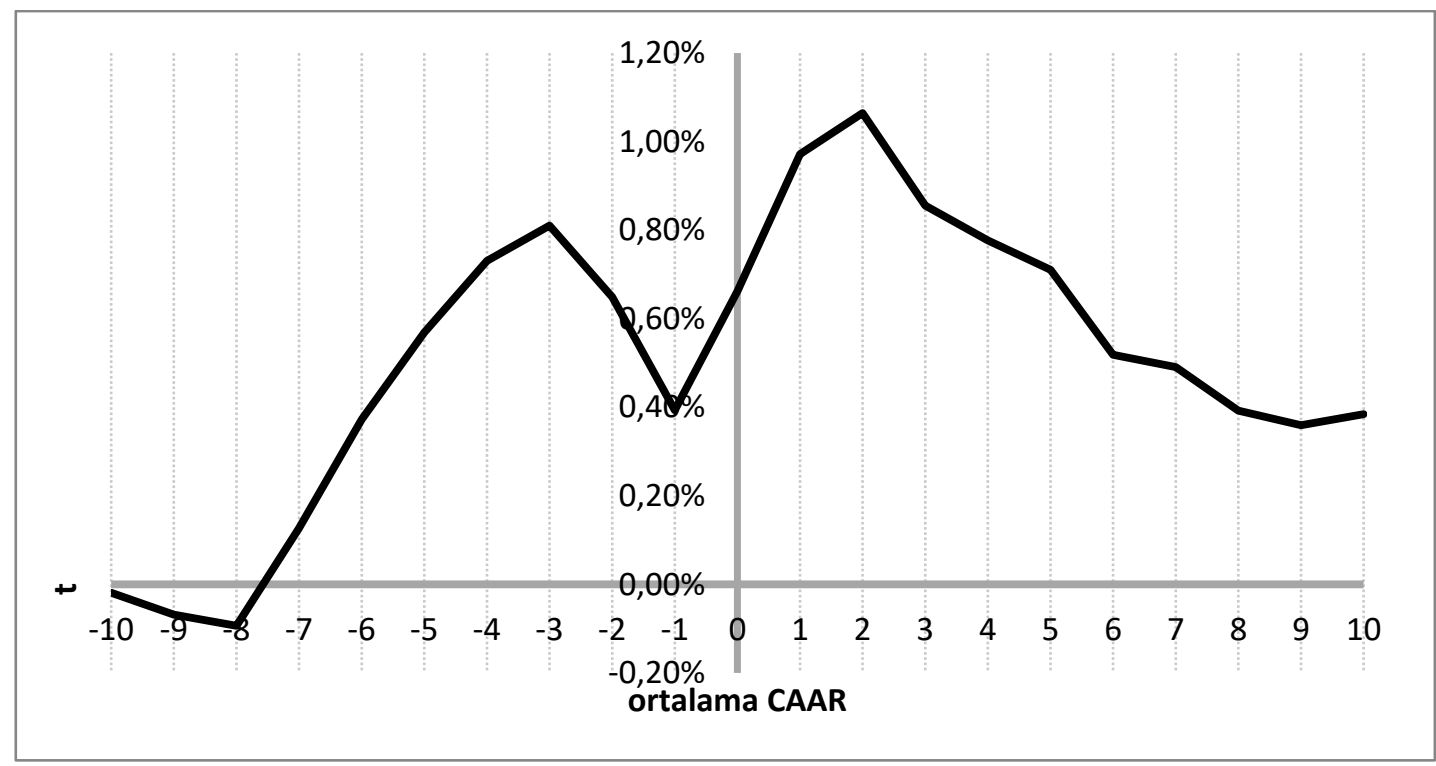

Şekil 3. Kümülatif Ortalama Anormal Getiri (CAAR) Değerlerinin Ortalaması

Yılların bireysel dalgalanmalarının yanında tüm yılların CAAR değerlerinin hareketinin karakteristiğini daha rahat görebilmek için ortalama CAAR değeri hesaplanmıştır. Şekil 3'te 
ortalama CAAR değerinin olay penceresi içindeki seyri görülebilir. Buna göre kümülatif ortalama anormal getirilerin ortalaması ilk iki gün negatif seyrettikten sonra pozitife dönmüş, olay öncesinde $t_{-}$'te ikinci en yüksek seviyesine ulaşırken, $t_{-1}$ 'de hızlı bir düşüş yaşamıştır. Ardından olay gününü de içine alan dönemde tekrar yükselerek $t_{+2}$ 'de en yüksek noktasına ulaşmıştır. Ancak bu tarih sonrasında ise düşüş eğilimi göstermiştir. Bu durum Brand Finance'in ilgili bilgiyi yıllık rapor öncesinde paylaşma politikasından kaynaklanabileceği ileri sürülebilir. Buna göre ortalama veriler incelendiğinde olaydan sekiz gün önce başlayan bir pozitif bir tepkinin olaydan üç gün önce tersine döndüğü, yine olay tarihinden bir gün önce başlayan pozitif tepkinin olaydan iki gün sonra sonlandığı görülebilir. Diğer bir ifade ile marka değeri duyurusu bilgisinin olay öncesinde iki kez fiyatlandığı, ilk geri dönüşün yine olay öncesinde, ikinci geri dönüşün ise olay sonrasında yaşandığı gibi bir sonuca ulaşılmaktadır. Bunun sebebinin ilgili bilginin piyasaya olay tarihinde bir bütün halinde değil, öncesinde parça parça gelme olasılığından kaynaklandığg düşünülmektedir.

\section{SONUÇ}

Hisse senetlerinin fiyatlarındaki dalgalanmalar ilgili firmalar açısında önem taşıyan bir durumdur. Fiyatların yönünü ve büyüklüğünü temel olarak firmalarla ilgili piyasaya gelen bilgiler belirler. Marka değeri özellikle nakit akışı yaratmaya olan etkisi açısından firma değeri anlamında önemlidir. Bu bakış açısıyla Türkiye'nin en değerli markalarına sahip firmalar arasına girebilmek bu firmalar için pozitif bir bilgidir ve hisse senedi fiyatlarını pozitif olarak etkilemesinin beklenmesi doğaldır. Bu çalışmada Brand Finance'in her yıl yayımlanan en değerli markalar sıralamasında ilk 10'a giren firmalar için bu durumun araştırılması amaçlanmıştır.

Tüm bulgular incelendiğinde beklenenin aksine yatırımcıların duyuruya yıllara göre birbirinden farklı şekillerde tepki gösterdikleri ileri sürülebilirken göze çarpan en önemli bulgu istatistiksel olarak anlamlı fiyat hareketlerinin araştırma döneminin ilk yıllarında olduğudur. Brand Finance'in Türkiye için ilk listeyi 2011'de yayımladığı, bu çalışmanın da 2012 ile 2017 yıllarını kapsadığı bilgisi ışığında yatırımcıların bu yeni ve görece beklenmeyen duruma ilk yıllarda daha çok pozitif ve anlamlı tepki verdikleri ancak yıllar içinde genellikle benzer firmaların listeye girdiği de düşünüldüğünde bu bilgiyi zaten fiyata yansıttıkları ileri sürülebilir. Bu bulgu ışığında da piyasanın etkinlik seviyesinin (Fama, 1991:1575) yıllar ilerledikçe arttığını ileri sürmek yanlış olmayacaktır. Diğer bir deyişle ilerideki yıllarda da marka değeri olarak ilk 10'a girecek firmaların hisse senetleri yardımıyla beklenenin üzerinde getiriler elde etme olasılı̆̆ 1 oldukça düşüktür.

Etkin Piyasalar Hipotezi açısından değerlendirildiğinde ise özellikle bazı yıllarda olay öncesinde gerçekleşmiş olan pozitif anormal getiri hakkında yorum yapmak yanıltıcı olabilecektir. $\mathrm{Bu}$ durumun marka değeri duyurularının piyasa tarafından doğru tahmin edilebileceği anlamına gelebileceği gibi ilgili kuruluşun marka değeri bilgilerini gerek kamuoyuyla gerekse listedeki firmalarla paylaşma politikasından kaynaklanabileceği unutulmamalıdır.

Tüm bu bulguların marka değerini ve hisse senedi değerini arttırmayı hedefleyen, en değerli markalar listesindeki firmalar, bireysel-kurumsal yatırımcılar ile sermaye piyasalarındaki düzenleyici ve denetleyici kurumlar açısından faydalı olacağı düşünülmektedir.

\section{KAYNAKÇA}

Aaker, D. A., \& Jacobson, R. (1994). The financial information content of perceived quality. Journal of marketing research, 191-201.

Aaker, D. A. (1996). Measuring brand equity across products and markets. California management review, 38(3) 
Aaker, D. A., \& Jacobson, R. (2001). The value relevance of brand attitude in high-technology markets. Journal of marketing research, 38(4), 485-493.

Agrawal, J., \& Kamakura, W. A. (1995). The economic worth of celebrity endorsers: An event study analysis. The journal of marketing, 56-62.

Altunışı, R., Özdemir, Ş., \& Torlak, Ö. (2006). Modern Pazarlama. İstanbul: Değissim Yayınları.

Barth, M. E., Clement, M. B., Foster, G., \& Kasznik, R. (1998). Brand values and capital market valuation. Review of accounting studies, 3(1-2), 41-68.

Basgoze, P., Yildiz, Y., \& Metin Camgoz, S. (2016). Effect of brand value announcements on stock returns: empirical evidence from Turkey. Journal of Business Economics and Management, 17(6), 1252-1269.

Bharadwaj, S. G., Tuli, K. R., \& Bonfrer, A. (2011). The impact of brand quality on shareholder wealth. Journal of Marketing, 75(5), 88-104.

Brown, S. J., \& Warner, J. B. (1985). Using daily stock returns: The case of event studies. Journal of financial economics, 14(1), 3-31.

Campbell, J. Y., Lo, A. W., \& MacKinlay, A.C. (1997). The econometrics offinancial markets. Chichester: Princeton University Press

Clark, B. (2002). Measuring performance: the marketing perspective. Business Performance Measurement. Theory and Practice, 22-39.

Cowan, A. R., \& Sergeant, A. M. (1996). Trading frequency and event study test specification. Journal of Banking \& Finance, 20(10), 1731-1757.

De Beijer, D., Dekimpe, M. G., Dutordoir, M., \& Verbeeten, F. H. (2008). The impact of brand value announcements on firm value.

Dutordoir, M., Verbeeten, F. H., \& De Beijer, D. (2015). Stock price reactions to brand value announcements: Magnitude and moderators. International Journal of Research in Marketing, 32(1), 34-47.

Fama, E. F. (1991). Efficient capital markets: II. The journal of finance, 46(5), 1575-1617.

Fehle, F., Fournier, S. M., Madden, T. J., \& Shrider, D. G. (2008). Brand value and asset pricing. Quarterly Journal of Finance and Accounting, 3-26.

Heding, T., Knudtzen, C. F., \& Bjerre, M. (2009). Brand management: Research, theory and practice. Routledge.

Hsu, F. J., Wang, T. Y., \& Chen, M. Y. (2013). The impact of brand value on financial performance. Advances in Management and Applied Economics, 3(6), 129.

Kapferer, J. (2008). The New Strategic Brand Management: Creating and Sustaining Brand Equity Long Term 4th edition (New Strategic Brand Management: Creating \& Sustaining Brand Equity).

Kotler, P., \& Keller, K. L. (2009). Marketing management 13e. New Jersey.

Kotler, P., Armstrong, G., Saunders, J., \& Wong, V. (1999). Priciples of Marketing (Second European Edition ed.). Upper Sadle River: Prentice Hall Inc.

MacKinlay, A. C. (1997). Event studies in economics and finance. Journal of economic literature, 35(1), 13-39.

Madden, T. J., Fehle, F., \& Fournier, S. (2006). Brands matter: An empirical demonstration of the creation of shareholder value through branding. Journal of the Academy of Marketing Science, 34(2), 224-235.

McWilliams, A., \& Siegel, D. (1997). Event studies in management research: Theoretical and empirical issues. Academy of management journal, 40(3), 626-657.

Mizik, N., \& Jacobson, R. (2008). The financial value impact of perceptual brand attributes. Journal of Marketing Research, 45(1), 15-32.

Topuz, Y. V., \& Aksit, N. (2016). The Effect of the Brand Value on Firm Value: an Empirical Implementation on Global Brands. British Journal of Marketing Studies, 4(1), 21-31.

http://brandfinance.com/images/upload/turkey_100_2017_unlocked.pdf (erişim tarihi: 12/08/2018)

http://brandfinance.com/images/upload/turkey_100_report_2016_for_print.pdf (erişim tarihi: 12/08/2018) 